\title{
Tindakan Diskresi Oleh Penyidik Dalam Penyelesaian Tindak Pidana Kekerasan Dalam Rumah Tangga di Polres Tanjung Jabung Barat
}

\author{
Sahuri Lasmadi, Umar Hasan, Elly Sudarti \\ Bagian Hukum Pidana Fakultas Hukum \\ Universitas Jambi
}

Email corresponding author: $\underline{\text { slasmadi@gmail.com }}$

\begin{abstract}
Penelitian ini dilatarbelakangi maraknya kekerasan yang terjadi dalam lingkup rumah tangga. KDRT merupakan jenis kekerasan yang memiliki sifat-sifat yang khas yakni dilakukan di dalam rumah, pelaku dan korban adalah anggota keluarga. Penelitian ini bertujuan: (1) Untuk Menganalisis Penyelesaian Tindak Pidana KDRT Melalui Tindakan Diskresi di Polres Tanjung Jabung Barat; (2) Untuk Menganalisis Dasar Hukum Tindakan Diskresi Dalam Penyelesaian Tindak Pidana KDRT; (3) Untuk Menganalisis Akibat Hukum Penerapan Tindakan Diskresi Dalam Penyelesaian Tindak Pidana KDRT di Polres Tanjung Jabung Barat. Metode Penelitian: penelitian ini merupakan penelitian yuridis normatif yang didukung dengan data empiris. Pendekatan yang digunakan adalah pendekatan perundang-undangan, pendekatan konseptual dan pendekatan kasus. Analisis bahan hukum dilakukan dengan cara menginterpretasi, menilai dan mengevaluasi undang-undang. Kesimpulan: (1) Penyelesaian pada tindak pidana KDRT sebanyak 14 kasus di Polres Tanjung Jabung Barat, diselesaikan penyidik dengan tindakan diskresi melalui mediasi yang lebih mengedepankan kemanfatan hukum; (2) Dasar hukum Tindakan Diskresi oleh Penyidik diatur pada Pasal 15 ayat (2) huruf k, Pasal 16 ayat (1) huruf L dan ayat (2), Pasal 18 ayat (1) dan ayat (2) Undang-undang Nomor 2 Tahun 2002 Tentang Kepolisian. Surat Kapolri Nomor Pol: B/3022/XII/2009/SDEOPS tanggal 14 Desember 2009 Tentang Penanganan Kasus Melalui Alternative Dispute Resolusion. Tindakan Diskresi dilakukan melalui mediasi penal belum diatur dalam Undang-Undang Nomor 23 Tahun 2004 Tentang Penghapusan Kekerasan Dalam Rumah Tangga; (3) Akibat hukum penerapan mediasi penal dalam penyelesaian tindak pidana KDRT adalah dapat menghapuskan status hukum tersangka pada diri pelaku. Saran: Untuk kepastian hukum perlu pembaharuan hukum tentang mediasi penal terhadap Undang-Undang Undang-Undang Nomor 23 Tahun 2004 Tentang Penghapusan Kekerasan Dalam Rumah Tangga.
\end{abstract}

Kata Kunci: Tindakan Diskresi, Penyidik, Kekerasan Dalam Rumah Tangga

\section{PENDAHULUAN}

Kepolisian Negara Republik Indonesia, adalah salah satu institusi pemerintah yang bertugas sebagai ujung tombak penegakan hukum di Indonesia. Tugas yang diemban ini tidaklah ringan karena akan berhadapan dengan masyarakat. Penegakan hukum, bukan saja masyarakat harus sadar hukum dan taat hukum, tetapi lebih bermakna pada pelaksanaan hukum sebagaimana mestinya dan bagi yang melanggar harus pula ditindak menurut prosedur dan ketentuan hukum yang berlaku.

POLRI sebagai penegak hukum yang bertugas memelihara ketertiban dan menjamin keamanan umum, memelihara keselamatan negara serta memelihara keselamatan orang, benda dan masyarakat termasuk memberi perlindungan dan pertolongan dan memberi serta mengusahakan ketaatan warga negara dan masyarakat terhadap segala bentuk-bentuk peraturan.

Tugas utama penyidik adalah: "mencari dan mengumpulkan bukti yang dengan buktibukti tersebut membuat terang tentang tindak pidana yang terjadi dan menemukan tersangka" POLRI sebagai penyidik karena kewajibannya mempunyai wewenang sebagimana ketentuan Pasal 7 ayat (1) Kitab Undang-Undang Hukum Acara Pidana (KUHAP), lebih lanjut wewenang tersebut juga diatur dalam Pasal 16 ayat (1) Undang-Undang Nomor 2 Tahun 2002 Tentang Kepolisan Negara Republik Indonesia. 
Pasal 18 Undang-Undang Nomor 2 Tahun 2002 Tentang Kepolisian Negara Republik Indonesia memberikan peluang pada aparat kepolisian untuk menerapkan diskresi sebagaimana diatur dalam Pasal 18 yang menyatakan bahwa:

1) Untuk kepentingan umum, pejabat Kepolisian Negara Republik Indonesia dalam melaksanakan tugas dan wewenangnya dapat bertindak menurut penilaiannya sendiri;

2) Pelaksanaan ketentuan sebagaimana dimaksud dalam ayat (1) hanya dapat dilakukan dalam keadaan yang sangat perlu dengan memperhatikan peraturan perundangundangan serta Kode Etik Profesi Kepolisian Negara Republik Indonesia.

Berdasarkan penjelasan Pasal 18 ayat (1) Undang-Undang Nomor 2 Tahun 2002 Tentang Kepolisian Negara Republik Indonesia menyebutkan bahwa yang dimaksud dengan "bertindak menurut penilaiannya sendiri" adalah suatu tindakan yang dapat dilakukan oleh anggota Kepolisian Negara Republik Indonesia yang dalam bertindak harus mempertimbangkan manfaat serta resiko dari tindakannya dan betul-betul untuk kepentingan umum.

Diskresi merupakan kewenangan kepolisian untuk mengambil keputusan atau memilih berbagai tindakan dalam menyelesaikan masalah pelanggaran hukum yang ditanganinya ${ }^{\mathrm{ii}}$. Tindakan diskresi oleh polisi dilakukan dengan cara mediasi penal. Mediasi penal merupakan alternatif penyelesaian perkara pidana di luar jalur penal ${ }^{\text {iii }}$. Dalam prakteknya, perkara diselesaikan secara musyawarah yang dimediasi oleh penyidik. Setelah diperoleh kesepakatan, korban mengajukan penarikan laporan ke penyidik, kemudian penyidik mengeluarkan surat perintah penghentian penyidikan (SP3) dengan alasan tidak cukup bukti, sehingga perkara tidak dilanjutkan. Cara penyelesaian perkara pidana seperti ini barangkali dapat memenuhi tuntutan keadilan dan kemanfaatan, namun bisa menjadi persoalan jika dilihat dari aspek legalitas dan kepastian hukum ${ }^{\text {iv }}$.

Tindakan diskresi oleh polisi sering kali dilakukan dalam penyelesaian tindak pidana KDRT. KDRT adalah setiap perbuatan terhadap seseorang terutama perempuan, yang berakibat timbulnya kesengsaraan atau penderitaan secara fisik, seksual, psikologis, dan/atau penelantaran rumah tangga termasuk ancaman untuk melakukan perbuatan, pemaksaan, atau perampasan kemerdekaan secara melawan hukum dalam lingkup rumah tangga ${ }^{\mathrm{v}}$. Sementara itu Undang-Undang Nomor 23 Tahun 2004 belum mengatur penyelesaian tindak pidana KDRT melalui mediasi penal.

Korban kekerasan biasanya rentan dialami oleh perempuan dan anak. Berbeda halnya dengan korban KDRT adalah orang yang mengalami kekerasan dan/atau ancaman kekerasan dalam lingkup rumah tangga"vi. Lingkup rumah tangga, tidak hanya suami, isteri dan anak, tetapi mencakup orang-orang yang tinggal dan menetap dalam rumah tersebut seperti, orang tua dari pihak suami atau isteri. Mereka yang dipandang sebagai anggota keluarga termasuk orang yang bekerja membantu rumah tangga dan menetap dalam jangka waktu selama berada dalam rumah tangga yang bersangkutan ${ }^{\text {vii }}$.

KDRT merupakan jenis kekerasan yang memiliki sifat-sifat yang khas yakni dilakukan di dalam rumah, pelaku dan korban adalah anggota keluarga. Jenis-jenis KDRT meliputi kekerasan fisik, kekerasan psikis, kekerasan seksual dan penelantaran dalam rumah tangga. Oleh sebab itu setiap orang dalam lingkup rumah tangga mempunyai potensi untuk menjadi pelaku maupun korban KDRT.

Dalam kasus kekerasan dalam rumah tangga tidak sedikit anggota keluarga yang melakukan kekerasan dijatuhi hukuman pidana, kekerasan yang dilakukan biasanya kekerasan secara fisik maupun psikis. Kekerasan fisik yang dimaksud adalah perbuatan yang mengakibatkan rasa sakit, jatuh sakit, atau luka berat ${ }^{\text {viii }}$. 
Di dalam UU PKDRT mengatur tindak pidana yang terdiri atas tindak pidana umum dan tindak pidana aduan. Ketentuan Pidana bagi pelaku KDRT tersebut diatur dalam Pasal 44 sampai dengan Pasal 53 UU PKDRT. Pengaduan merupakan hak dari korban untuk diadakan penuntutan atau tidak dilakukan penuntutan karena menyangkut kepentingan korban, untuk itu dalam perkara tindak pidana aduan diberikan jangka waktu pencabutan perkara yang diatur dalam Pasal 75 KUHP.

Tindak pidana aduan kekerasan dalam rumah tangga diatur dalam Pasal 51, Pasal 52 dan Pasal 53 UU PKDRT yang secara tegas disebutkan diantaranya:

1) Pasal 51: "Tindak pidana kekerasan fisik sebagaimana dimaksud dalam Pasal 44 ayat (4) merupakan delik aduan".

2) Pasal 52 : "Tindak pidana kekerasan psikis sebagaimana dimaksud dalam Pasal 45 ayat (2) merupakan delik aduan".

3) Pasal 53: "Tindak pidana kekerasan seksual sebagaimana dimaksud dalam Pasal 46 yang dilakukan oleh suami terhadap isteri atau sebaliknya merupakan delik aduan".

Dengan demikian pasal-pasal ketentuan pidana selain pasal-pasal di atas adalah tindak pidana umum juga tindak pidana aduan, dimana tindak pidana aduan yaitu apabila ada pengaduan dari korban tindak pidana, maka pengaduan dapat dicabut apabila ada perdamaian atau perjanjian damai sebelum lewat waktu 3 (tiga) bulan. Berbeda pada tindak pidana umum, tindak pidana tidak bisa dihentikan prosesnya meskipun korban sudah memaafkan atau pelaku mengganti kerugian, proses hukum terus berlanjut sampai putusan pengadilan karena pada prinsipnya perdamaian tidak bisa menghapus tindak pidana, tetapi dapat menjadi dasar pertimbangan yang meringankan secara sosiologis ketika hakim memutuskan tindak pidana tersebut.

Berdasarkan data dari Kepolisian Resort Tanjung Jabung Barat diketahui bahwa jumlah kasus kekerasan dalam rumah tangga dari laporan yang diterima tahun 2015 sampai dengan tahun 2019 berjumlah 14 (empatbelas) kasus. Keseluruhan kasus berhasil diselesaikan secara diskresi. Dari Tindakan diskresi pada kasus KDRT di Kepolisian Resort Tanjung Jabung Barat dilakukan pada tindak pidana umum yang melanggar Pasal 44 ayat (1) UU PKDRT.

Kasus KDRT tidak secara otomatis diselesaikan dengan tindakan diskresi. Dalam hal ini penyidik menilai setiap perkara yang diterima untuk diproses apakah patut dilakukan diskresi atau tidak. Menarik untuk diteliti lebih lanjut mengenai: (1) Bagaimana Penyelesaian Tindak Pidana KDRT Melalui Tindakan Diskresi di Polres Tanjung Jabung Barat? (2) Apa Dasar Hukum Tindakan Diskresi Dalam Penyelesaian Tindak Pidana KDRT? (3) Bagaimana Akibat Hukum Penerapan Tindakan Diskresi Dalam Penyelesaian Tindak Pidana KDRT di Polres Tanjung Jabung Barat?

\section{METODE PENELITIAN}

Kajian tentang "Tindakan Diskresi Oleh Penyidik Dalam Penyelesaian Tindak Pidana Kekerasan Dalam Rumah Tangga di Polres Tanjung Jabung Barat" dalam artikel ini dilakukan dengan menggunakan metode yuridis normatif dengan didukung data empiris. Penelitian ini menggunakan pendekatan perundang-undangan, menurut B.J. Nasution yaitu penelitian terhadap produk undang-undang ${ }^{\mathrm{ix}}$, selanjutnya pendekatan konseptual dan pendekatan kasus. Penelitian ini menggunakan bahan hukum primer dan sekunder. Analisis bahan hukum dilakukan dengan cara: menginterpretasikan, menilai dan mengevaluasi. 


\section{PEMBAHASAN}

\subsection{Penyelesaian Tindak Pidana Kekerasan Dalam Rumah Tangga Melalui Tindakan Diskresi oleh Penyidik di Polres Tanjung Jabung Barat}

Salah satu bentuk perlindungan yang harus dimiliki setiap orang adalah perlindungan dari kekerasan baik dalam ranah personal, ranah komunitas, maupun ranah negara. Perkembangan dewasa ini menunjukkan bahwa tindak kekerasan secara fisik, psikis, seksual, maupun ekonomi justru banyak terjadi dalam ranah personal atau lingkup rumah tangga, dimana yang sering menjadi korban adalah perempuan dan anak. Jika dilihat dari karakteristiknya, KDRT merupakan jenis kekerasan yang memiliki sifat-sifat khas yakni dilakukan di dalam rumah tangga, pelaku dan korban adalah anggota keluarga serta seringkali dianggap bukan sebagai bentuk kekerasan.

Ketentuan pidana dalam Undang-Undang PKDRT diatur dari Pasal 44 sampai dengan Pasal 53 dengan ancaman pidana berupa penjara atau denda. Beberapa dari ketentuan pidana tersebut merupakan tindak pidana aduan yaitu Pasal 44 ayat (4), Pasal 45 ayat (2) dan Pasal 46, sementara yang lainnya merupakan tindak pidana umum. Terhadap perkara KDRT dengan tindak pidana aduan sering diselesaikan secara damai di Tingkat Kepolisian dengan kewenangan diskresinya.

Kepolisian Negara Republik Indonesia (POLRI) merupakan lembaga pemerintahan yang mempunyai tugas pokok di bidang penegakan hukum, memelihara keamanan dan ketertiban masyarakat. Dalam pelaksanaannya, tugas pokok anggota POLRI, sesuai dengan asas negara hukum di Republik Indonesia, maka pelaksanaan tugas harus didasarkan kepada hukum yang berlaku.

Salah satu tugas polisi sebagai penegak hukum adalah menanggulangi tindak pidana. Sebagai penyidik pada prinsipnya melakukan tindakan penyidikan pada semua perkara pidana yang terjadi, tetapi di lain pihak sebagai penyidik polisi dalam melakukan penyidikan tindak pidana dapat melakukan tindakan diskresi dalam rangka penyelesaian tindak pidana tersebut, sebagaimana yang dilakukan oleh para penyidik di Polres Tanjung Jabung Barat dalam menangani tindak pidana kekerasan dalam rumah tangga melalui mediasi penal.

Mediasi penal sebagai salah satu alternatif dalam penyelesaian dianggap sesuai karena sifat dasar mediasi yang memberikan kekuasaan sepenuhnya kepada para pihak untuk menentukan jalannya proses dan hasil kesepakatan yang diinginkan. Keputusan yang diambil bukan merupakan keputusan dari pihak ketiga sebagai mediator, tetapi kehendak dan kemauan penuh dari pihak yang berperkara dalam hal ini pasangan suami istri yang terlibat dalam kasus KDRT.

Terjadinya tindak pidana diketahui oleh Pihak Kepolisian melalui, laporan, pengaduan, tertangkap tangan maupun ketika melakukan patroli.

\section{Laporan}

Laporan adalah "Pemberitahuan yang disampaikan oleh seorang karena hak atau kewajiban berdasarkan undang-undang kepada pejabat yang berwenang tentang telah atau sedang atau diduga akan terjadi peristiwa pidana"x

Pelapor bisa korban atau yang dikuasakan bahwa telah terjadi suatu tindak pidana. Pelapor dapat langsung datang ke kantor Kepolisian terdekat pada lokasi tindak pidana tersebut terjadi. Laporan tersebut disampaikan kepada Sentra Pelayanan Kepolisian Terpadu (SPKT) yang bertugas memberikan pelayanan kepolisian secara terpadu terhadap laporan/pengaduan masyarakat, memberikan bantuan dan pertolongan, serta memberikan 
pelayanan informasi. Peristiwa yang dilaporkan belum tentu tindak pidana, sehingga dibutuhkan penyelidikan oleh pejabat yang berwenang untuk menentukan perbuatan tersebut merupakan tindak pidana atau bukan.

Dalam kasus KDRT, sebelum dibuat laporan Polisi dilakukan introgasi terlebih dahulu terhadap pelapor. Pelapor bisa korban sendiri atau keluarga yang dikuasakannya. Pada saat yang bersangkutan melapor, pelapor dipertemukan oleh petugas Sentra Pelayanan Kepolisian Terpadu dan piket Reskrim untuk menemui penyidik di Ruangan Sat Reskrim atau Ruang Perlindungan Perempuan dan Anak. Selanjutnya penyidik mengklarifikasi kepada korban apakah kasus ini benar kekerasan dalam rumah tangga lalu kasus tersebut akan dilanjutkan atau tidak. Polisi akan menyarankan kepada pelapor bahwa kasus KDRT sebaiknya diselesaikan secara kekeluargaan.

Jika korban tetap berkeinginan untuk melaporkan perkara KDRT tersebut maka Polisi tidak akan melakukan konseling lagi dan meminta korban untuk membuat laporan Polisi, membuat pengaduan yang dibubuhi materai oleh yang bersangkutan atau keluarga yang dikuasakannya, kemudian dari pihak Unit Perlindungan Perempuan dan Anak mengantar yang bersangkutan untuk melakukan Visum di Rumah Sakit, hasil Visum sebagai alat bukti untuk membuat Laporan Polisi. Pada tahap penyelidikan Polisi selanjutnya mengirimkan surat kepada saksi-saksi, pelaku dan korban untuk guna diminta keterangan, dengan melakukan pemeriksaan terhadap korban dan saksi-saksi, dan pelaku. Hasil pemeriksaan dituangkan dalam Berita Acara Keterangan (BAK). Kemudian berdasarkan bukti permulaan yang cukup Polisi akan melakukan upaya penangkapan, kemudian membawa pelaku ke Kantor Polisi untuk dilakukan proses penyidikan lebih lanjut.

Kepolisian Tanjung Jabung Barat dari tahun 2015 - 2019 telah menerima sebanyak 14 LAPORAN kasus KDRT, dari ke 14 (empatbelas) kasus ini merupakan pelanggaran atas Pasal 44 ayat (1 ) Undang-Undang Nomor 23 Tahun 2003 Tentang PKDRT.

Laporan Polisi berisikan antara lain: (1) Orang yang melaporkan; (2) peristiwa yang dilaporkan (waktu kejadian, tempat kejadian, apa yang terjadi, siapa terlapor dan korban, bagaimana terjadi, tanggal pelaporan); (3) Tindak Pidana yang dilanggar; (4) Barang Bukti; (5) Nama dan Alamat Saksi; (6) Uraian singkat kejadian; (7) Tanda tangan pelapor (pelapor bisa saja bukan korban); (8) Tindakan yang diambil (membuat Laporan Polisi, mencatat saksi-saksi, Koordinasi Piket Reskrim, Cek TKP, Visum); (9) Mengetahui Kapolres; (10) Tanda tangan yang menerima laporan.

\section{Pengaduan}

Pengaduan adalah "Pemberitahuan disertai permintaan oleh pihak yang berkepentingan kepada pejabat yang berwenang untuk menindak menurut hukum seorang yang telah melakukan tindak pidana aduan yang merugikannya" "xi .

Di dalam tindak pidana aduan, seorang yang merasa dirugikan akan membuat pengaduan ke Kantor Polisi terdekat tentang peristiwanya, berbeda dengan tindak pidana umum, tindak pidana aduan tidak dapat diproses jika tidak ada pengaduan dari pihak yang merasa dirugikan. Pengaduan menjadi dasar untuk dilakukannya penuntutan. Pengaduan dapat dicabut sebelum lewat watu 3 (tiga) bulan.

Dari data tahun 2015-2019 di atas bahwa umumnya pelaku tindak pidana kekerasan dalam rumah tangga didominasi oleh suami sebagai kepala rumah tangga. Pada tahun 2015 ada 1 (satu) kasus kekerasan dalam rumah tangga pelaku adalah suami. Tahun 2016 terdapat 3 (tiga) kasus kekerasan dalam rumah tangga dan semua pelaku adalah suami. Pada tahun 2017 terdapat 5 (lima) kasus, 4 (empat) pelaku diantaranya adalah suami dan 1 (satu) pelaku adalah istri. Pada tahun 2018 terdapat 3 (tiga) kasus, pelaku adalah suami dan tahun 2019 terdapat 2 
(dua) kasus, satu kasus pelakunya adalah suami dan satu kasus pelakunya anak.

Adapun yang menjadi korban dalam tindak pidana KDRT yang diproses di Polres Tanjung Jabung Barat selama tahun 2015-2019 pada umumnya yang menjadi korban kekerasan dalam rumah tangga adalah isteri. Pada tahun 2015 kasus KDRT berjumlah 1 (satu) kasus dimana korbannya adalah isteri. Pada tahun 2016 kasus kekerasan dalam rumah tangga berjumlah 3 (tiga) kasus dan korban semuanya adalah istri, selanjutnya pada tahun 2017 ada 5 (lima) kasus kekerasan dalam rumah tangga dimana 4 (empat) korban adalah istri dan 1 (satu) korban adalah suami. Pada tahun 2018 terdapat 3 (tiga) kasus, korbannya adalah isteri. Tahun 2019 terdapat 2 (dua) kasus, korbannya adalah satu orang istri dan satu orang ibu. Dari paparan kasus di atas, perempuan rentan menjadi korban KDRT.

Penyidik Polres Tanjabbar dalam menangani kasus kekerasan dalam rumah tangga sejak awal mengupayakan perdamaian kepada para pihak, sehingga kasus KDRT tidak ada yang dilanjutkan ke tahap penuntutan. Dalam pemeriksaan pertama penyidik memanggil korban untuk menyelesaikan kasus ini secara mediasi dengan batas penyelesaian damai selama 3 (tiga) bulan dengan mempertemukan keluarga kedua belah pihak antara korban dan pelaku ke Polres Tanjung Jabung Barat untuk menemukan solusi atas kasus yang mereka hadapi.

Pada pemeriksaan awal biasanya korban menolak saran dari pihak Unit Perlindungan Perempuan dan Anak untuk dilakukan mediasi penal karena korban sudah terlanjur sakit hati atas tindakan yang dilakukan suaminya tersebut. Biasanya korban ataupun para pihak diberikan kesempatan untuk berpikir ulang tentang kasusnya, diberikan rentang waktu sebelum lewat waktu 3 (tiga) bulan. Berdasarkan hasil penelitian kesepakatan damai antara pelaku dan korban tercapai masih pada masa penyelidikan dan penyidikan. Sebanyak 6 (enam) kasus tercapai mediasi masih tahap penyelidikan, sedangkan 8 (delapan) kasus tercapai mediasi pada masa penyidikan.

Para pihak yang telah sepakat untuk berdamai, dibuatlah surat perjanjian perdamaian secara tertulis di atas materai yang ditandatangani oleh kedua belah pihak beserta saksi-saksi yang diketahui oleh RT/ RW/ Kepala Desa/Kepala Kelurahan setempat. Perdamaian dapat tercapai baik pada tahap penyelidikan maupun penyidikan.

Perjanjian perdamaian yang tercapai pada tahap penyelidikan, pada intinya bahwa kesepakatan perdamaian berisi tentang kesediaan pelaku untuk meminta maaf kepada korban dan keluarganya dan berjanji tidak akan akan mengulangi lagi perbuatannya. Menariknya bahwa meskipun kedua belah pihak saling memaafkan dan bersedia untuk mencabut laporan, tetapi pada LP/B-127/XII/2017/RES TJB BRT/ SPKT, Tanggal 8 Desember 2017. Perjanjian damai berisi korban meminta pelaku untuk menceraikannya. Pada LP/B-110/IX/2018/RES TJB BRT/SPKT, Tanggal 13 September 2018. Korban meminta kepada pelaku untuk mengabulkan permohonan cerai kedua pihak dan biaya perceraian ditanggung oleh pelaku. Pada LP/B8/IV/2015/RES JTB BRT/SPKT Tanggal 15 Mei 2015, korban akan menggugat cerai dan semua biaya yang dikeluarkan ditanggung oleh pelaku.

Pada tahap penyidikan ini terdapat 2 (dua) kasus yang dilakukan penahanan terhadap pelaku. LP/B-35/III/2018/RES TJB BRT/SPKT, Tanggal 8 Maret 2018, perdamaian tercapai pada tahap penyidikan, pelaku dilakukan penahanan selama 4 (empat) hari. LP/B69/VII/2017/RES TJB BRT/SPKT, Tanggal 27 Juli 2017. Pelaku sempat ditahan selama 9 (Sembilan) hari. Kesepakatan perdamaian tercapai pada tahap penyidikan, berdasarkan isi perjanjian tersebut korban bersedia untuk mencabut laporan/pengaduan yang ditujuan ke Polres Tanjabbar, maka selanjutnya Kapolres menerbitkan Surat Perintah Pengeluaran Tahanan Nomor SP.Han/48 - e/ VIII/2017/Reskrim.

Selanjutnya penyidik mengadakan gelar perkara. Masing-masing peserta gelar perkara KDRT menyampaikan pendapatnya terkait dengan hasil gelar perkara dan hasilnya dikirim ke Kapolres Tanjung Jabung Barat sebagai bahan untuk mengambil keputusan apakah perkara 
tersebut dapat diselesaikan di luar pengadilan atau tetap melalui tahap sistem peradilan pidana.

Kapolres Tanjung Jabung Barat berdasarkan fakta dan pendapat dari peserta gelar perkara mengizinkan penyelesaian perkara KDRT di luar pengadilan, maka penyidik tetap menyelesaikan berita acara pemeriksaan dengan lengkap dan surat pemberitahuan dimulainya penyidikan tidak dikirim ke Penuntut Umum. Kemudian penyidik mencatat perkara tersebut dalam buku register. Perkara yang masih berada pada tahap penyelidikan Pihak Polres mengeluarkan Surat Ketetapan Tentang Penghentian Penyelidikan yang ditandatangani oleh Kapolres yang selanjutnya diberitahukan kepada pelapor dan berlaku sejak tanggal dikeluarkan. Dengan demikian diambil kebijakan berupa tindakan diskresi untuk menghentikan penyelidikan maupun penyidikan karena antara pelaku dan korban telah berdamai.

Dari 14 (empatbelas) kasus tindak pidana kekerasan dalam rumah tangga yang diselesaikan dengan mengambil tindakan diskresi untuk menghentikan penyidikan karena para pihak telah berdamai, kesemuanya pelaku dijerat dengan Pasal 44 ayat (1) Undang-Undang Nomor 23 Tahun 2004 Tentang Penghapusan Kekerasan Dalam Rumah Tangga.

Kepolisian sebagai penyidik dapat menggunakan diskresinya untuk dilakukannya upaya mediasi penal yang bertindak sebagai mediator dari kedua belah pihak. Mediasi mempunyai keunggulan karena apabila ada masyarakat melapor tentang adanya kasus KDRT di lingkup keluarganya kemudian pelapor tersebut dapat di mediasi oleh Polisi dan bisa diselesaikan secara kekeluargaan itu sangat membantu Kepolisian terutama membantu kedua belah pihak untuk kembali hidup bersama dan menjaga keutuhan keluarga dan memperhatikan kepentingan masa depan keluarga dan anaknya. Tidak selamanya bahwa adanya perdamaian diharapkan rumah tangga korban utuh kembali, hasil penelitian ini menunjukkan terdapat tiga kasus dimana korban walaupun telah berdamai tetapi korban mengajukan permohonan perceraian.

Penyidik Polres Tanjung Jabung Barat menggunakan kebijakan diskresi dalam penyelesaian tindak pidana kekerasan dalam rumah tangga, dengan pertimbangan bahwa yaitu hukum pidana merupakan jalan terakhir, jangan menggunakan hukum pidana jika masih ada sarana lain yang lebih efektif. Mengingat penggunaan hukum pidana dapat menimbulkan stigmatisasi seseorang menjadi penjahat sehingga sulit diterima oleh masyarakat.

Tindakan diskresi melalui mediasi penal oleh penyidik Polres Tanjung Jabung Barat atas perkara tindak pidana kekerasan dalam rumah tangga dinilai sangat efektif dan dianggap berhasil, sementara itu mediasi penal tersebut belum diatur dalam perundang-undangan/hukum positif terutama belum diatur di dalam Undang-Undang Nomor 23 Tahun 2004 Tentang Penghapusan Kekerasan Dalam Rumah Tangga sebagai alternatif penyelesaian perkara karena di dalam Undang-Undang tersebut hanya melakukan penerapan sanksi pidana penjara dan pidana denda sebagai alternatif pemidanaan dalam penyelesaian perkara kekerasan dalam rumah tangga tersebut.

\subsection{Dasar Hukum Tindakan Diskresi Dalam Penyelesaian Tindak Pidana Kekerasan Dalam Rumah Tangga}

Salah satu pembaharuan hukum yang diinginkan adalah penyelesaian perkara pidana kekerasan dalam rumah tangga dengan menggunakan pendekatan keadilan restoratif. Pelaksanaan Penyelesaian perkara dengan pendekatan keadilan restoratif belum dimasukkan sebagai proses alternatif penyelesaian tindak pidana kekerasan dalam rumah tangga di dalam Undang-Undang Nomor 23 Tahun 2004 Tentang Penghapusan Kekerasan Dalam Rumah Tangga.

Secara normatif perlu adanya pengaturan mediasi penal dalam tindak pidana kekerasan dalam rumah tangga terhadap jenis-jenis kekerasan fisik, psikis, seksual yang tidak menimbulkan luka berat, dan sakit di tubuh korban, hampir semua tindak pidana kekerasan dalam rumah tangga diselesaikan melalui mediasi penal. 
Tidak adanya landasan peraturan yang mengatur tentang mediasi penal tersebut khususnya terhadap tindak pidana kekerasan dalam rumah tangga membuat penyidik harus melakukan diskresi terhadap suatu tindak pidana kekerasan dalam rumah tangga. Dalam penyelesaian tindak pidana KDRT dengan menggunakan mediasi penal di Tingkat Kepolisian dilakukan oleh penyidik yang bertindak sebagai mediator, dalam hal ini penyidik ditunjuk oleh Kapolres melalui surat perintah, penyidik diberikan kebebasan dalam menyelesaikan tindak pidana KDRT, padahal proses mediasi tersebut tidak diatur di dalam Undang-Undang Nomor 23 Tahun 2004 Tentang Penghapusan Kekerasan Dalam Rumah Tangga. Hal ini menjadi masalah yang sangat penting dimana Indonesia sebagai negara hukum dan sistem hukum acara pidana harus berlandaskan peraturan yang berlaku.

Dalam praktiknya di Kepolisian Tanjung Jabung Barat, walaupun tidak ada landasan hukum formalnya tindak pidana KDRT hampir seluruhnya Laporan Polisi yang diterima diselesaikan di luar proses pengadilan melalui diskresi aparat penegak hukum, mekanisme perdamaian, lembaga adat, secara kekeluargaan dan sebagainya.

Tujuan penghapusan penghapusan penghapusan kekerasan dalam rumah tangga, yaitu: (a) Mencegah segala bentuk kekerasan dalam rumah tangga; (b) Melindungi korban kekerasan dalam rumah tangga; (c) Menindak pelaku kekerasan dalam rumah tangga, dan (d) Memelihara keutuhan rumah tangga yang harmonis dan sejahtera ${ }^{\text {xii }}$.

Beberapa Pasal di dalam Undang-Undang Nomor 2 Tahun 2002 Tentang Kepolisian Negara Republik Indonesia dapat dijadikan dasar hukum bagi aparat kepolisian untuk menerapkan mediasi penal melalui pelaksanaan kewenangan diskresi kepolisian dalam proses penegakan hukum pidana, antara lain:

1) Pasal 15 ayat (2) huruf k Undang-Undang Nomor 2 Tahun 2002 Tentang Kepolisian Negara Republik Indonesia, yang menyebutkan: "Kepolisian Negara Republik Indonesia sesuai dengan peraturan perundang-undangan lainnya berwenang melaksanakan kewenangan lain yang termasuk dalam lingkup tugas kepolisian".

2) Pasal 16 ayat (1) huruf L Undang-Undang Nomor 2 Tahun 2002 Tentang Kepolisian Negara Republik Indonesia: "Dalam rangka menyelenggarakan tugas dibidang proses pidana, Kepolisian Negara Republik Indonesia berwenang untuk mengadakan tindakan lain menurut hukum yang bertanggung jawab". Ayat (2): "Tindakan lain sebagaimana dimaksud dalam ayat (1) huruf $\mathrm{L}$ adalah tindakan penyelidikan dan penyidikan yang dilaksanakan jika memenuhi syarat sebagai berikut:

(1) Tidak bertentangan dengan suatu aturan hokum;

(2) Selaras dengan kewajiban hukum yang mengharuskan tindakan tersebut dilakukan;

(3) Harus patut, masuk akal, dan termasuk dalam lingkungan jabatannya;

(4) Pertimbangan yang layak berdasarkan keadaan yang memaksa;

(5) Menghormati hak asasi manusia.

3) Pasal 18 ayat (1) Undang-Undang Nomor 2 Tahun 2002 Tentang Kepolisian Negara Republik Indonesia: "untuk kepentingan umum, pejabat Kepolisian Negara Republik Indonesia dalam melaksanakan tugas dan wewenangnya dapat bertindak menurut penilaiannya sendiri". Ayat (2): "Pelaksanaan ketentuan sebagaimana dimaksud dalam ayat (1) hanya dapat dilakukan dalam keadaan yang sangat perlu dengan memperhatikan peraturan perundang-undangan, serta Kode Etik Profesi Kepolisian Negara Republik Indonesia".

4) Surat Kapolri Nomor Pol: B/3022/XII/2009/SDEOPS tanggal 14/12/2009 Tentang Penanganan Kasus Melalui Alternative Dispute Resolusion, merumuskan sebagai berikut: 
(1) Mengupayakan penanganan kasus pidana yang mempunyai kerugian materi kecil, penyelesaiannya dapat diarahkan melalui konsep ADR.

(2) Penyelesaian kasus pidana dengan menggunakan ADR harus disepakati oleh pihak-pihak yang berperkara namun apabila tidak terdapat kesepakatan baru diselesaiakan sesuai dengan prosedur hukum yang berlaku secara profesional dan proporsional.

(3) Penyelesaian kasus pidana yang menggunakan ADR harus berprinsip pada musyawarah dengan menyertakan RT/RW setempat.

(4) Penyelesaian kasus pidana dengan menggunakan ADR harus menghormati norma hukum sosial atau adat serta memenuhi azas keadilan.

(5) Memberdayakan anggota Polmas dan memerankan FKPM yang ada di wilayah masing-masing untuk mengindentifikasi kasus-kasus pidana yang mempunyai kerugian materiil kecil dan memungkinkan untuk diselesaiakan melalui konsep ADR.

(6) Untuk kasus yang telah dapat diselesaikan melalui konsep ADR agar tidak lagi disentuh oleh tindakan hukum lain yang kontra produktif dengan tujuan Polmas.

Surat Kapolri Nomor Pol:B/322/XII/2009/SDEOPS tanggal 14/12/2009 tersebut pada dasarnya bukan merupakan produk hukum dalam arti perundang-undangan, namun dapat juga dikatakan sebagai peraturan kebijakan, sebagai pedoman bagi kepolisian dalam menangani perkara pidana yang termasuk dalam kategori yang dimaksud dalam Surat Kapolri tersebut.

Pasal 15 ayat (2) huruf k, Pasal 16 ayat (1) huruf L dan ayat (2), Pasal 18 ayat (1) dan (2) Undang-Undang Nomor 2 Tahun 2002 Tentang Kepolisian dan Surat Kapolri Nomor Pol:B/322/XII/2009/SDEOPS tanggal 14/12/2009 adalah dasar hukum bagi pihak Kepolisian dalam mengambil tindakan diskresi. Dari beberapa peraturan tersebut tidak ada mengatur upaya mediasi penal secara lengkap dan bagaimana pelaksanaannya. Jika dilihat dari efektifitas penggunaan upaya mediasi penal seharusnya diatur di dalam hukum positif Indonesia khususnya pengaturan mediasi penal di dalam Undang-Undang Nomor 23 Tahun 2004 Tentang penghapusan Kekerasan Dalam Rumah Tangga ${ }^{\text {xiii }}$.

Penyidik menggunakan tindakan diskresi untuk menyelesaikan perkara Kekerasan Dalam Rumah Tangga melalui non litigasi (mediasi penal). lebih menitik beratkan kepada kemanfatan hukum terciptanya keadilan dan keseimbangan bagi pelaku tindak pidana serta korbannya sendiri dan prosesnya tidak terlalu lama serta tidak mengeluarkan biaya yang terlalu besar. Tujuan mediasi penal ini sendiri sangatlah baik bagi penegak hukum, pelaku dan korban. dalan rumah tangga. Dari sisi hukum mediasi penal belum memberikan kepastian hukum, oleh karena proses penyelesaian KDRT di luar pengadilan belum diatur di dalam Undang-Undang Nomor 23 tahun 2004 tentang PKDRT.

\subsection{Akibat Hukum Penerapan Mediasi Penal Dalam Penyelesaian Tindak Pidana Kekerasan Dalam Rumah Tangga di Polres Tanjabbar}

Tindak pidana kekerasan dalam rumah tangga merupakan terdiri atas tindak pidana umum dan tindak pidana aduan yang penyelesaiannya melalui proses peradilan atau dapat diselesaikan dengan adanya perdamaian atau mediasi kedua belah pihak yang berperkara untuk menghentikan proses penyidikan di Kepolisian. Dalam tindak pidana KDRT penyidik Polres Tanjabbar umumnya memberikan masukan kepada pihak yang berperkara untuk melakukan mediasi sebagai alternatif penyelesaian perselisihan di luar pengadilan jika kekerasan yang ditimbulkan akibat kasus kekerasan dalam rumah tangga tersebut merupakan kekerasan ringan sifatnya. Penyidik sebagai mediator memberikan masukan dan saran kepada korban agar 
menyelesaikan kasus KDRT yang dialaminya secara kekeluargaan. Mediasi, tidak berarti untuk meniadakan pertanggungjawaban pelaku kejahatan. Masyarakat sangat mengutamakan dan menginginkan kemanfaatan hukum dan keadilan. Masyarakat Kota Tungkal sangat kental dengan adat istiadat dalam menyelesaikan perselisihan melalui cara kekeluargaan daripada melalui jalur ke Pengadilan. Mediasi ini dilakukan selama pihak yang berselisih menginginkan untuk didamaikan dan jika kedua belah pihak setuju, maka perkara tindak pidana KDRT tidak dilanjutkan.

Secara teknis, penyidik Polres Tanjabbar tidak mengalami kendala dalam melakukan tindakan diskresi dalam menyelesaikan tindak pidana KDRT secara mediasi penal karena dalam pelaksanaannya penyidik memberikan kebebasan kepada para pihak yang berperkara untuk memilih penyelesaian perkaranya, tetapi penyidik Polres Tanjabbar akan melihat, menilai, tingkat kerugian fisik maupun materi yang dialami oleh korban tindak pidana KDRT. Akibat yang ditimbulkan oleh pelaku dan korban dalam menyelesaikan tindak pidana kekerasan dalam rumah tangga melalui mediasi penal yaitu Status hukum terhadap pelaku dihubungkan dengan Pasal 75 KUHP yang menyatakan: "orang yang mengajukan pengaduan, berhak menarik kembali dalam waktu tiga bulan setelah pengaduan diajukan" apabila penerapan mediasi penal disetujui oleh kedua belah pihak lalu membuat surat perdamaian, kemudian korban mencabut laporannya di Kepolisian maka otomatis menghilangkan status tersangka pada diri pelaku dan perkara kekerasan dalam rumah tangga tersebut dihentikan oleh penyidik.

Jika proses mediasi terlaksana dan berhasil, korban mengajukan surat permohonan pencabutan laporan, selanjutnya penyidik mengadakan pemeriksaan saksi korban lanjutan, bahwa korban-benar-benar ingin mencabut laporan tanpa paksaan dari pihak manapun. Berita acara ditandatangani oleh Pemohon (korban) dan Penyidik yang memeriksa, maka proses penyidikan dihentikan dan tidak berlanjut ke Pengadilan.

\section{KESIMPULAN DAN SARAN}

1. Penyelesaian pada tindak pidana KDRT sebanyak 14 kasus di Polres Tanjung Jabung Barat, diselesaikan penyidik dengan tindakan diskresi melalui mediasi yang lebih mengedepankan kemanfatan hukum

2. Dasar hukum Tindakan Diskresi oleh Penyidik diatur pada Pasal 15 ayat (2) huruf k, Pasal 16 ayat (1) huruf L dan ayat (2), Pasal 18 ayat (1) dan ayat (2) Undang-Undang Nomor 2 Tahun 2002 Tentang Kepolisian. Surat Kapolri Nomor Pol: B/3022/XII/2009/SDEOPS tanggal 14/12/2009 Tentang Penanganan Kasus Melalui Alternative Dispute Resolusion.

3. Akibat hukum penerapan mediasi penal dalam penyelesaian tindak pidana KDRT adalah dapat menghapuskan status hukum tersangka pada diri pelaku.

Untuk kepastian hukum perlu adanya pembaharuan hukum tentang mediasi penal terhadap Undang-Undang ini karena pada dasarnya prinsip dari Undang-Undang Nomor 23 Tahun 2004 Tentang Penghapusan Kekerasan Dalam Rumah Tangga.

\section{DAFTAR PUSTAKA}

Bahder Johan Nasution, Metode Penelitian Ilmu Hukum, Penerbit CV Mandar Maju, Bandung, 2008.

Jakarta, 1997.

Kitab Undang-Undang Hukum Pidana (KUHP); 
Komisi Kepolisian Nasional, DISKRESI KEPOLISIAN: Dalam Tinjauan Hukum dan Implementasinya di lapangan, Jakarta, 2013.

Leden Marpaung, Proses Penanganan Perkara Pidana, (Penyelidikan dan Penyidikan), Sinar Grafika, Jakarta, 2011.

R Abdussalam, Hukum Kepolisian Sebagai Hukum Positif dalam Disiplin Hukum, Jakarta, 2009.

R Abdussalam, Penegakan Hukum di Lapangan Oleh POLRI, Dinas Hukum Polri,

Sahuri Lasmadi, "Mediasi Penal Dalam Sistem Peradilan Pidana Indonesia", Disampaikan Dihadapan Kalangan Hakim Dari 2 (dua) Lingkungan Peradilan Di Wilayah Jambi, Hotel Novita, Jambi 2011.

Undang-Undang Nomor 2 Tahun 2002 Tentang KepolisianRepublik Indonesia;

Undang-Undang Nomor 23 Tahun 2004 Tentang Pemberantasan Kekerasan Dalam Rumah Tangga;

Undang-Undang Nomor 8 Tahun 1981 Kitab Undang-Undang Hukum Acara Pidana (KUHAP);

Usman dan Andi Najemi, "Mediasi Penal di Indonesia: Keadilan, Kemanfaatan dan Kepastian Hukum”, Undang Jurnal Hukum, Vol. 1 No 1 (2018).

\section{ENDNOTE}

${ }^{\mathrm{i}}$ Leden Marpaung, Proses Penanganan Perkara Pidana (Penyelidikan dan Penyidikan), Sinar Grafika, Jakarta, 2011, hlm. 1.

${ }^{\mathrm{ii}}$ R. Abdussalam, Penegakan Hukum di Lapangan Oleh POLRI, Dinas Hukum POLRI, Jakarta, 1997, hlm. 26.

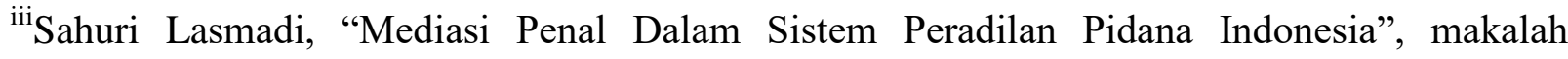
disampaikan dalam Lokakarya Hakim, Jambi, 2011, hlm. 1-2.

${ }^{\text {iv } U s m a n ~ d a n ~ A n d i ~ N a j e m i, ~ " M e d i a s i ~ P e n a l ~ d i ~ I n d o n e s i a: ~ K e a d i l a n, ~ K e m a n f a a t a n ~ d a n ~}$ Kepastian Hukum”, Undang Jurnal Hukum, Vol. 1 No 1 (2018), hlm. 68.

vLihat Pasal 1 angka 1 Undang-Undang Nomor 23 Tahun 2004

${ }^{\mathrm{vi}}$ Lihat Pasal 3 Undang-Undang Nomor 23 Tahun 2004

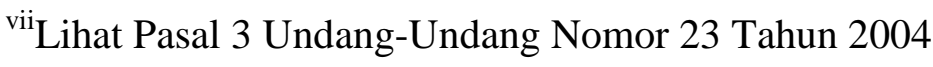

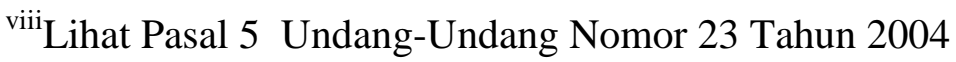

${ }^{\mathrm{ix}}$ Bahder Johan Nasution, Metode Penelitian Ilmu Hukum, Penerbit Mandar Maju, Bandung, 2008, hlm. 92.

${ }^{\mathrm{x}}$ Lihat Pasal 24 Undang-Undang Nomor 8 Tahun 1981

${ }^{x i}$ Pasal 25 Undang-Undang Nomor 8 Tahun 1981

xii Lihat Pasal 4 Undang-Undang Nomor 23 Tahun 2004 
xiii Wawancara dengan Dian Kris Utami, Penyidik Pembantu Unit Pelayanan Perempuan dan Anak Polres Tanjung Jabung Barat, tanggal 1 Agustus 2019. 